\title{
青野原俘虜収容所捕虜兵のスポーツ活動
}

岸本肇

\section{Sportliche betätigungen der Gefangenen im Kriegsgefangenenlager Aonogahara}

\section{Hajime Kishimoto}

\section{Zusammenfassung}

Dieser Artikel versucht, anhand der Dokumente, Zeitungsartikel und Fotos die sportlichen Betätigungen deutscher Kriegsgefangener im Kriegsgefangenenlager Aonogahara in der Präfektur Hyogo während des Ersten Weltkriegs aufzuzeigen. Als Ergebnis der Untersuchung läßt sich zusammenfassend aussagen: 1) Bei den Disziplinen, die die Kriegsgefangenen im Lager trieben, handelte es sich hauptsächlich um Turnen, Fußball, Tennis, Kegeln, Faustball, Schlagball, Billiard und Ausflüge. Im Vergleich mit den anderen Kriegsgefangenenlagern in Japan bestent kaum ein Unterschied in den Disziplinen. 2) Unter den Sportorganisationen im Lager etablierte sich der Turnverein am besten. 3) Das Turnfest und das Leichtathletikturnier zählten zu den größten Veranstaltungen im Lager. 4) Als sportlicher Austausch mit der einheimischen Bevölkerung wurden Fußballspiele mit Mannschaften des örtlichen Gymnasiums und der Lehrerbildungsanstalt durchgeführt. 5) Einem Ersuchen der Kriegsgefangenen, aktiv Sport treiben zu dürfen, wurde von der Lagerverwaltung stattgegeben. Jedoch waren die Bedingungen für die Ausübung von Sport nicht für alle Gefangenen einheitlich. 6) Der Waffenstillstand bot den Gefangenen die große Gelegenheit, ihre sportlichen Betätigungen weiter zu entwickeln. 7) Die Lagerverwaltung hielt der Sport für effektiv, nicht nur um die Gesundheit der Gefangenen zu erhalten, sondern auch um ihre Langeweile vorzubeugen.

\section{Schlüsselwörter : der Erste Weltkrieg, Deutschland, Kriegsgefangene, Turnen}

(Japan J. Phys. Educ. Hlth. Sport Sci. 50: 285-294, May, 2005)

キーワード：第1次世界大戦，ドイツ，捕虜，ト

$$
\text { ウルネン }
$$

\section{Iはじめに}

青野ヶ原 ${ }^{21)}$ は，兵庫県明石市の北方約 $30 \mathrm{~km}$ に位置する丘陵である。ここに，いまは自衛隊の

神戸大学発達科学部

厂 657-8501神戸市灘区鶴甲3-11

連絡先 岸本 肇
Faculty of Human Development, Kobe University

3-11 T'surukabuto, Nada-ku, Kobe 657-8501

Correspondingauthor kisimoto@kobe-u.ac.jp 
駐屯地と演習場があるが，かつて陸軍演習場があ った。 その一角に，第1次世界大戦中，青野原俘

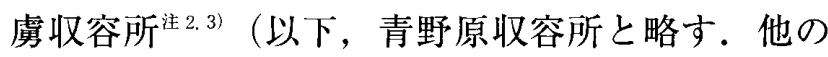
収容所についても初出後は同様に略す)があった。 収容されていたのは，中国山東省青島における日 独戦争の際，日本軍の捕虜となったドイツ軍兵士 である。当時，日本にはドイッ軍捕虜兵注4)用に 12 収容所あったが，それらは最終的に6収容所に 統廃合された，青野原収容所はその中の1つであ り，1914年11月 11 日から開設されていた姫路俘 虜収容所が，1915年 9 月 20 日に青野ヶ原に移転 した収容所である。そこから，最後の捕虜兵が州 国したのは 1920 年 1 月 27 日である.

青野原収容所には，1918年 4 月の統計 ${ }^{35)} に よ$ ると, 日独戦争の捕虜総人数の約 1 割 477 人が収 容されていた。その内訳に抏いて，ドイッ兵とオ 一ストリア・ハンガリー帝国兵がほぼ半々という ことと，特にオーストリア・ハンガリー帝国兵の 人数が，日本に囚われていた同帝国捕虜兵の約 8 割ということが, 他収容所の人数構成と異なる特 徴であった。

そのような青野原収容所であるが，板東俘虜収 容所のように一般に知られていないし，これまで ほとんど研究もされていない，その大きな理由と して，板東収容所における“Die Baracke”注5), 松山俘虜収容所における “Lagerfeuer”注6) のよう な「収容所新聞」の類が見当たらないことがある。 捕虜兵の母国側においても，第1次世界大戦に関 する研究や記録等を 1931 年に集録した “In Feindeshand” ${ }^{34}$ が，日本にある捕虜収容所の 1 つと して青野原収容所を挙げている程度である。比較 的最近のKlein ${ }^{12}$ の研究においても, 同様である. しかしながら 1992 年以降, 兵庫県小野市の市史 編纂作業の過程において, 青野原収容所捕虜兵の 生活と諸活動に関する史料が収集され ${ }^{22}$ ，彼らの スポーツ活動について一般史研究者の関心も引い ている ${ }^{13)}$.

第 1 次世界大戦中，日本に抑留されていたドイ ツ軍捕虜兵のスポーツ活動に関する研究は, これ までそのすべてが山田 ${ }^{38)} に$ 依拠していたといっ ても過言ではない。,山田は, その中で, 捕虜兵の
文化・スポーツ活動に「寛大」であったとされる 板東収容所においても，そうではなかったとされ る久留米俘虜収容所，松山収容所においても，ス ポーツをする組織があり, 多様なスポーツ活動が 展開していたことを明らかにしている。しかし青 野原収容所に関する山田の知見は，それが主要な 研究対象ではない限界から，「体操班」の日課的 活動の指摘 ${ }^{46)}$ と, テニス施設存在の推察 ${ }^{45)}$ に止 まっている.

そこで本研究においては，そのように不透明な 青野原収容所捕虜兵の姫路収容所時代を含む 5 年 3 ケ月の間のスポーツ活動に関して, 種目と行事, 組織, 地域交流, 捕虜兵の要求と日本側の管理方 針等について，下記の史料をもとにして事実や内 容を解明することを主たる目的とする.

本研究で用いる文書, 新聞以外の主たる史料は, 元捕虜兵の日記注7), スポーツ関係の写真である. その中の多くは, Laan ${ }^{\text {ia } 8)}$ 経由で小野市史料編纂 室へ寄贈されたものである。写真は，筆者が Schmidt ${ }^{\text {ì } 9)}$ から直接提供を受けた。板東収容所 における “Unser Turnen in Bando”注10), 久留米 収容所に执ける“Turnen und Sport”注11) のよう なスポーツ関係の出版物は, 青野原収容所に関し ては未発掘である。

なお，以下の論述に際して，近年，それぞれの 市教育委員会が研究に取り組んでいる久留米収容 所と習志野俘虜収容所に関する知見も引用して, 青野原収容所におけるスポーツ活動を特徴づける ようにする。

\section{II＼cjkstart青野原収容所における スポーツ活動の展開}

\section{1. スポーツ種目の分布}

捕虜兵が帰国した後に俘虜情報局が編纂し， 1920 年 7 月 15 日に陸軍大臣田中義一に提出した 『大正 3 年乃至 9 年戦役俘虜顛末』 ${ }^{28)}$ では，姫路収 容所と青野原収容所における捕虜兵のスポーツ活 動について，「…彼等八各自目課 則正シク勉強ショク連動セり…」[注）下線筆者］ と総括している。そして具体的に，「郊外散歩」 「撞球等ノ競技」「蹴球『テニス』拳闘, 体操等の 
諸運動」を挙げている。そのうち, 蹴球と撞球, すなわちサッカーとビリヤードの様子は, 同じ俘 虜情報局により捕虜兵の抑留中に作成された写真 集で窅うことができる ${ }^{4 / \text { i玉 }}$ (2).

当時の新聞記事と国内文書記録をもとにして， 青野原収容所捕虜兵の主たるスポーツ活動につい て，記載された日付順にまとめたのが表1である。

これによると，最初の約 10 ヶ月間，姫路時代 は遠足と収容所の寺院境内でできる程度の運動で あったが，青野ヶ原に移ってからスポーツらしい 種目が増えていることがわかる.場所が広くなり， 捕虜生活がそれなりに落ち着いたからであろう。 そして例えば, サッカーは週 1, 2 回, 遠足は月 1 , 2 回の頻度で, ビリヤードは営業活動として実施 されていたこともわかる゙131.

元捕虜兵の当時の日記，帰国後の回想録の中で も収容所におけるスポーツの様子が散見される。 Kerstenは，「1個ボールが寄贈されると，退屈し のぎに，サッカーとファウストバルの熱狂者が現 れた。ボールで寺の屋根瓦や塀を損壊した．空の ビール瓶を売った金でダンベルを調達した、鉄棒

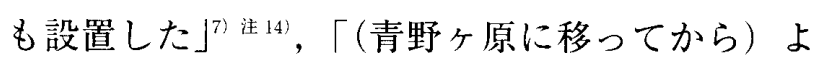
くスポーツをするようになった。 ‥週 1 回，サッ カー, シュラークバル，ケーゲル等を収容所の外 側ですることを許された」委と日記に止めている. ダンベル運動や，新聞に表記されている種目名 (表1参照) ではわかりにくかったファウストバ ル, シュラークバル, ケーゲルもやられていたこ とがわかる.オーストリア・ハンガリー帝国兵で

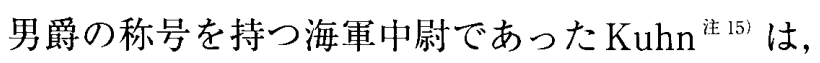
組立て体操のピラミッドの光景を“Turnübungen in Aonogahara”（青野ヶ原におけるトゥ ルネン運動）の見出しをつけた写真で示し，さら にテニスコートを 2 面つくり, トゥルネン器械を 立てたと, 回想している ${ }^{36}$.

水泳については, 兵庫県加東郡社町大門の蓬萊

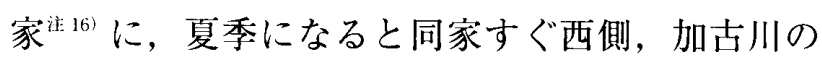
川港があり軍隊や学校の水泳訓練の適地であった 場所へ，捕虜兵が来ていたという話が先代から伝 わっている.

以上のような青野原収容所捕虜兵のスポーツ活
動の種目分布は，山田による「日本国内のドイッ 兵俘虜収容所における体育・スポーツ活動」表 にあるものと基本的には同じである，ただし，板 東収容所 ${ }^{391}$ や久留米収容所 ${ }^{31}$ においてはその 「クラブ」湆 17) まで組織され，習志野収容所 ${ }^{19)}$ でも 盛んであったホッケーに関しては，表 1 に記載が ないごとく，青野原収容所においては新聞で紹介 されるほど目立っていなかったようである。

\section{2. スポーツ行事}

1917 年 10 月 30 日, スペイン公使が青野原収容 所を視察に訪れている，下の引用文は，そのとき の収容所長宮本秀一中佐の「口演要旨 ${ }^{25)}$ からの 抜粋である。

\section{六, 娛楽の件}

3 , 体育ニ八非常ナル興味ヨ有スル結果当春 ヨリ体操会ヨ実施シ時々競技会ク開催シ日夜 練習二余念ナシ最近二於テ九月十七日二一回

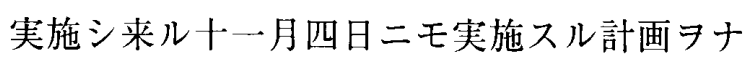
シツツン
(マ) アリ
[注）下線筆者]

図 1から, “TURNFEST-AONOGAHARA 1917”（トゥルネン祭 青野ヶ原 1917）が読み 取れるが，この写真は上記の引用文にある「競技 会」に関係する印刷物であろう。

1917 年といえば, 捕虜兵の抑留 3 年目に当たる 年である。「我等八日本ノ俘虜トナリテ既ニ三ヶ 年ヨ経過セル今日ナレハ今少シ自由ヨ与ヘラル , 様取計レ度」25) とする収容所側の捕虜兵管理姿勢 の軟化が，そのような組織的なトゥルネン活動を 容認する背景にあったと考えられる。ちなみに， 板東収容所の開設は，1917年 4 月である.

Kerstenの日記には，次のように，サッカー, 陸上競技，テニス等の行事もあったことが記され ている。「サッカー以外にも，2，3のスポーツ行 事が開催された。走，跳，投の試合で，私は $1500 \mathrm{~m}$ 走と 3 種競技（100m，やり投げ，高跳び） に出場した.われわれの『金持ち』から賞金とし て10円ずつ提供されることもあった。・収容所 内で,われわれはもっと小規模な行事も開催した. その1つがテニスの試合である」 $\rfloor^{6}$.

上の引用文は，日記の中で，展覧会の思い出に 
表 1 青野原俘虜収容所捕虜兵の主なスポーツ活動

\begin{tabular}{|c|c|c|c|}
\hline 年月日 & 戦況の推移と捕虜兵の動向 & スポーツ等の内容 & 出 典 \\
\hline 1914.6.28 & $\begin{array}{l}\text { サラエボ事件 } \\
\text { オーストリア皇太子がセルビア青年 } \\
\text { に暗殺される }\end{array}$ & & \\
\hline 7.28 & 第 1 次世界大戦勃発 & & \\
\hline 8.23 & 日本がドイツに宣戦布告 & & \\
\hline 8.25 & $\begin{array}{l}\text { 日本がオーストリア・ハンガリー帝 } \\
\text { 国に宣戦布告 }\end{array}$ & & \\
\hline 10.31 & $\begin{array}{l}\text { 日英連合軍青島ドイツ要塞へ総攻撃 } \\
\text { 開始 }\end{array}$ & & \\
\hline 11.7 & 青島ドイッ軍降伏 & & \\
\hline 11.13 & $\begin{array}{l}\text { 捕虜兵の姫路収容所（3 寺院に分散） } \\
\text { の収容開始 }\end{array}$ & & \\
\hline 11.22 & & 毎朝, 食後に境内で<運動 $>$ & 鴊城新聞 \\
\hline 12.2 & & 姫路城へ＜遠足＞ & $\begin{array}{l}\text { 神戸又新日報 } \\
\text { 鷺城新聞 }\end{array}$ \\
\hline 12.4 & & $\begin{array}{l}\text { く木片のラケット>でテニス（〈フット， } \\
\text { ボール>が, 境内が狭くできないため) }\end{array}$ & 神戸又新日報 \\
\hline 12.5 & & $\begin{array}{l}\text { 「狭隘な庭園で型ばかりの<アセッション式 } \\
\text { のフッドール }\end{array}$ & 神戸又新日報 \\
\hline 1915.1.7 & & 市川へ＜遠足＞ & 大阪朝日新聞 \\
\hline 4.6 & & 夢前川へ＜遠足＞ & 大阪朝日新聞 \\
\hline 6.7 & & 広峰山へ＜遠足＞ & 大阪朝日新聞 \\
\hline 9.20 & 姫路収容所から青野原収容所へ移動 & & \\
\hline 12.22 & & 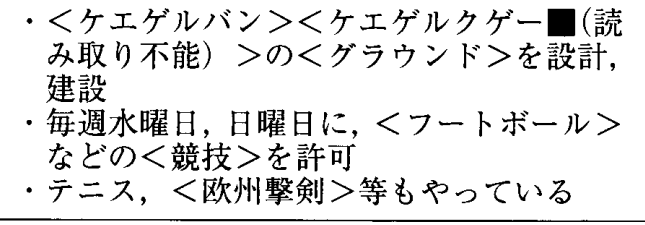 & 神戸又新日報 \\
\hline 1916.5.17 & & $\begin{array}{l}\text { ・青野ヶ原では所内で運動ができるので,姫 } \\
\text { 路の頃ほど外出したがらない,「漸く } 12 \text { 回 } \\
\text { 外出」 } \\
\text { ·所内では運動は怠らずにやっている }\end{array}$ & 神戸新聞 \\
\hline 5.24 & & $\begin{array}{l}\text { ·「俘虜の玉突き屋開業」 } \\
\text { ・毎週月, 水の両日は構外でくフートボー } \\
\quad \text { ル }\end{array}$ & 神戸又新日報 \\
\hline 8.23 & & $\lceil\cdots$ 稀二引卒外出ヨナシ運動シッっアリ‥」 & 文献 23） \\
\hline 1917.10.30 & & 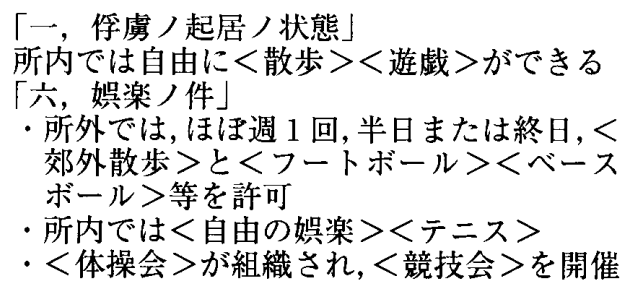 & 文献 25） \\
\hline 11.23 & & 「テニスコートで無邪気な＜遊戯＞」 & 神戸又新日報 \\
\hline 1918.11.11 & 休戦条約 & & \\
\hline $12.13-20$ & 展覧会 & 陸上競技大会（開催日特定できず） & 文献 6) \\
\hline 1919.5.22 & & $\begin{array}{l}\text { • <散歩>の途中に, 小野中学校蹴球部と } \\
\text { サッカ試合 } \\
\text { • その後数回, 小野中学校が青野ヶ原へ行 } \\
\text { き, サッカーの試合をする }\end{array}$ & 文献 5） \\
\hline 6.28 & ベルサイユ条約 & & \\
\hline 7.13 & & $\begin{array}{l}\text { 姫路師範学校と小野中学校が「獨逸俘虜と球 } \\
\text { 戰」 }\end{array}$ & 大阪朝日新聞 \\
\hline 9.10 & サンジェルマン条約 & & \\
\hline
\end{tabular}


12.27 第一陣袖戸上り㷌国

1920.1.27最後の捕虜兵を送り出す

2.29 青野原収容所残務整理終了, 閉鎖

4.1 青野原収容所廃止

注 1）「」は引用を示す.く >は原文どおりの表現であることを示す.

注 2）出典が新聞の場合，年月日はそれが報道された日付である.

注 3）〈フット，ボール><フートボール>はフットボール，明らかにサッカーである. 〈アセッション式のフット ボール〉はアソシエーション（式）フットボール，これもサッカーである.

注 4）〈ケエゲルバン>はケーゲルバーン，すなわちドイッ伝統の「ボウリング」であるケーゲルのレーン，<ケエ ゲルクゲー

>はケーゲル用のクーゲル (ボール) であろう。

注 5）〈ベースボール>と野球は，ドイツ伝統のクリケット風球技であるシュラークバルをさしているか，書き手の 勘違いであろう。

注 6）〈バレーボール>は，拳でボールを打つドイッ式の「バレーボール」であるファウストバルをさしているか, 書き手の勘違いであろう。

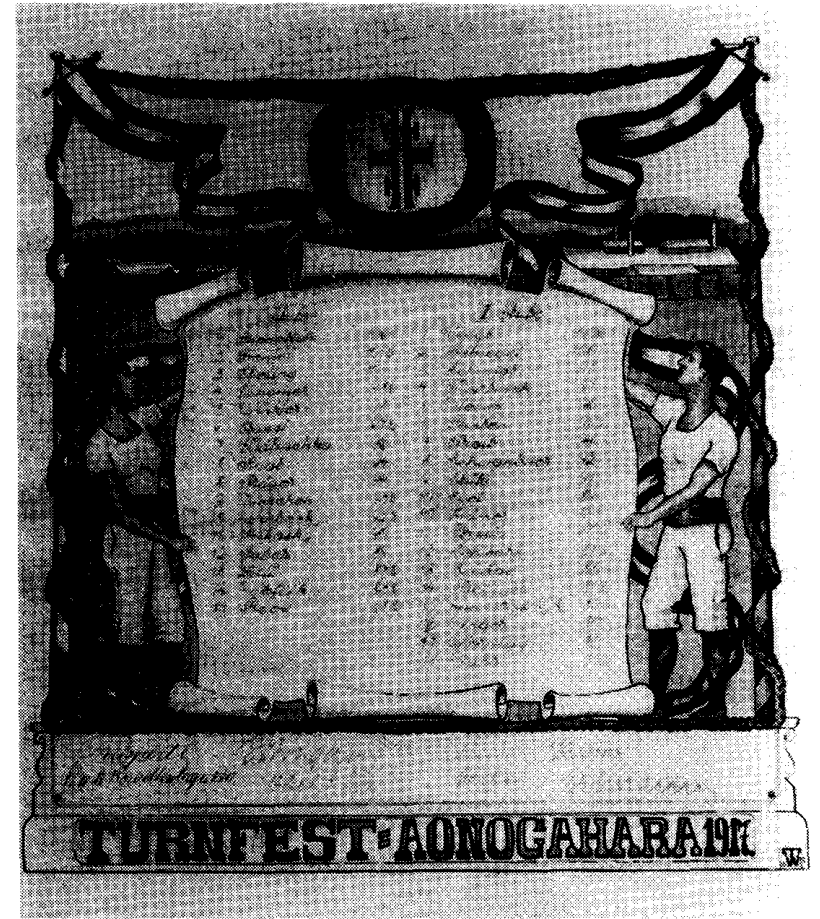

図1 “TURNFEST-AONOGAHARA 1917” (Schmidt 氏所蔵)

連続して書かれている，青野原収容所における展 覧会開催 ${ }^{26)}$ は，1918年 12 月の「青野原俘虜収容 所ドイッ・オーストリア・ハンガリー兵製作品展 覧会」2)の1回だけである。そのことから判断す ると，大規模な陸上競技大会は，その開催期間中
かその前後の時期に開催されていた可能性が高 い.

その規模や頻度は別にして, 青野原収容所でも, 板東収容所 ${ }^{41}$, 久留米収容所 ${ }^{31}$, 習志野収容所 ${ }^{191}$ のように，トゥルネン祭，陸上競技大会の行事， サッカー，テニスの試合等が開催されていたのは 間違いがないと考えられる。

\section{3.スポーツ組織と組織上の民族問題}

板東収容所にはスポーツ活動全体を統轄する 「スポーツ委員会 ${ }^{39}$ が，久留米収容所には運動場 の使用割当てを調整する「運動場管理委員会 ${ }^{433}$ が，松山収容所には競技大会を掌る「競技委員 会」4、があったことを，山田は明らかにしている。 そして，それら「委員会」のもとで活動していた 各種スポーツの“Verein”“Vereinigung” “Gesellschaft”に，それぞれ「クラブ」の訳語を 当てている ${ }^{i: 18)}$.

そのように「委員会」を立ち上げてスポーツ活 動を管理・運営するやり方は，軍隊的生活を送っ ていた捕虜兵の世界だけに特有ではない。例えば, 第 1 次世界大戦中, イギリス人の「軍役年齢の 文民」（civilian of military age）を収容していた ベルリン郊外の “The Ruhleben Prison Camp” 


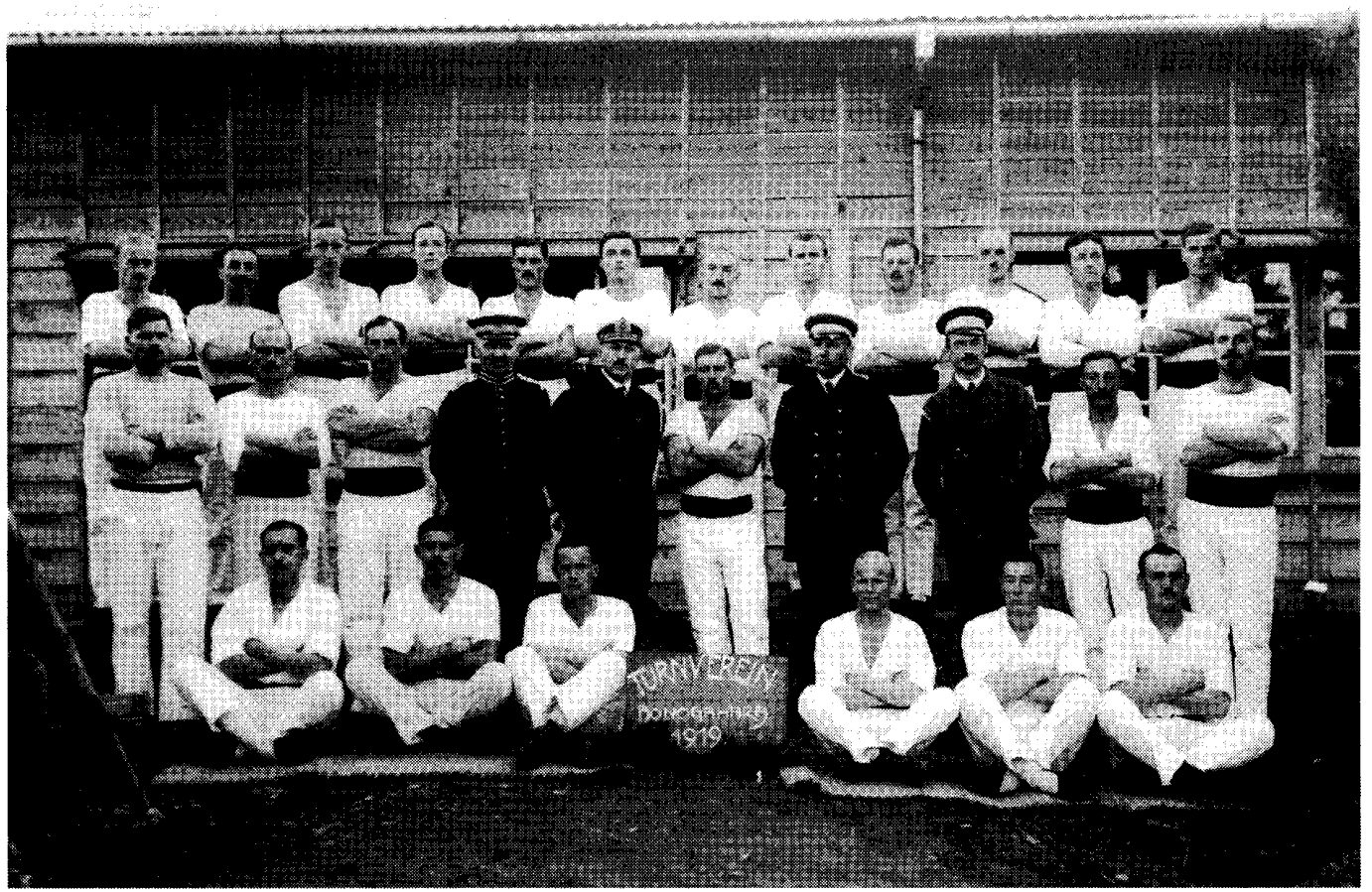

図2 “TURNVEREIN AONOGAHRA 1919”

(Schmidt 氏所蔵)

にも，「スポーツ統制委員会」(The Sports Control Committee) ${ }^{11}$ があった。

青野原収容所においても，スポーツ活動のため の何らかの「委員会」や種目別「クラブ」があっ たと推定されるが，現在，スポーツ組織でその存 在が確認できるのは“TURNVEREIN IN AONOGAHARA 1919”の写真（図2）によるトゥルネ ンクラブのみである注19).

〈I〉で説明したように，青野原収容所には，ド イッ兵以外にオーストリア・ハンガリー帝国兵も いた，特にオーストリア・ハンガリー帝国兵の民 族構成は多様で, 言語, 宗教の違いもあり, 彼ら の間で争論が絶えなかったという ${ }^{17}$. スラブ系兵 (チェコ人，ポーランド人，クロアチア人）約 50 人を，他の捕虜兵の集団が，収容所から追い出そ うとした事件も起こっている ${ }^{10)}$. しかし，そのよ うな軋軪に伴うスポーツ実施上の問題について は，オーストリア・ハンガリー帝国士官であった $\mathrm{Kuhn}^{36)}$ も書き残していない.

前節冒頭で述べた 1917 年 10 月のスペイン公使 の青野原収容所訪問は，オーストリア・ハンガリ 一帝国兵の視察が主たる目的であったが，そのと
きの日本側報告文には「…公使ハ一週間二二回郊 外運動 為シ得ル イタリ」 ${ }^{25)}$ 以外に，スポーツへの配慮事項は何も 記載されていない.

新聞が「將校兵卒の隔たりなく」77) とか「今日 は日曜日とて何れも喜んで遊んでるる，独墺俘虜 何れも $ل^{14)}$ [注）下線筆者］と報じている例がある ように，表面的には，スポーツする捕虜兵の様子 は階級にも民族にもとらわれていないと見えてい たのだろう。

\section{III スポーツの地域交流}

「本年［筆者注）1919年］五月二十二日午後蹴 球部が小會を催さんとするや，ゆくりなくも彼の 青野原の一隅に窘めらる>, 俘虏の團体百五十餘 名監督官に引率せられて散歩しつ>本校[筆者注） 旧制兵庫県立小野中学校＼cjkstart門前にて休毠するに逢 う」卓。そして，たちまち両者間に「情意相投ずる ものありしにや」゙, サッカーの日独対抗戦が始ま った。試合後, 捕虜兵はさらに「器械体操の運動 振を演じ」 ${ }^{5)}$, 小野中学校側は「剣, 柔道の仕合及 
柔道形」占を見せている。

「これが縁となり其後我よりも數回靑 (ママ) 野原 に出掛け彼 ${ }^{\text {(マ) }}$ と練習的仕合をなし，頗得る所あ りき」5゙だったという。1919年 7 月 13 日に青野ヶ 原で実施された小野中学校対捕虜兵, 姫路師範学 校対捕虜兵の「球戦」21) は，その頃のサッカー試 合の1つであろう。

板東収容所 ${ }^{42)}$ でも久留米収容所 ${ }^{18)}$ でも, 地元 生徒が捕虜兵のスポーツ活動の参観に訪れている が，その際に生徒と捕虜兵がサッカーの試合まで した形跡はない. 地元中学生, 師範学校生と捕虜 兵とのサッカー交流は, 青野原収容所に招けるス ポーツ活動の中で特筆すべき出来事である。こう いうスポーツ交流ができるようになった背景とし て，1918年 11 月に調印された休戦条約後の「平 和克服氣分というものか $ل^{21)}$ という社会状況を考 えておかなくてはならない。

\section{IV 捕虜兵のスポーツ要求と日本側の対応}

\section{1. 要求して実現したスポーツ}

捕虜は何といっても囚われの身である．抑留 4 年目の 1918年 7 月になっても，青野原収容所捕 虜兵が赤十字国際委員会に訴え出た内容は，「上 申・教育（会合）の抑圧」 ${ }^{29}$ 「講演講習会活動の禁 止」32) という有様であった。事実, 収容所側はそ れまでに，「兒戯的喜遊 ${ }^{300}$ 注20)の「風教上コノマ シカラサル」吕) 影響や伝染病を口実として遠足を 中止したり ${ }^{3)}$ ，建造物損壊の罰としてスポーツを やらせないこと7があった。

そのように管理された中で, 「‥,1915年以来, 戦友たちは多くの要望を出していた。特にテニス コートへの要望が強く, 2 面が, 適度の広さの 2 棟のバラックの間を利用して作られた」尚。砲術, 土木, 建築，造船，その他の技師がたくさんいた ので，ケーゲルのバーンは自分達で作れた ${ }^{17)}$. 「体操ハ…体操班ヨ構成シ自ラ資 $コ$ 投シテ鐵棒, 横木, 超越臺等 設ケ」た ${ }^{28)}$. ビリヤード台は, 購入された ${ }^{16)}$.ケーゲルの用具は遠く上海から取 り寄せられた ${ }^{17}$. 捕虜兵が，自らの労働力と資力 でスポーツする施設・用具を整えたのは, 捕虜兵
の諸活動に寛大であったとされる板東収容 所 ${ }^{40)}$ だけではないのである.

しかし，スポーツはだれでも平等にやれたわけ ではない．2等砲兵であった Kerstenが，「テニ スコートはよく利用されたが，全員が利用できた というわけではなく, 自分でラケットや球や靴等 の装備を買ったり借りたり出来る者に限られてい た」家「金満家は2 面テニスコートをつくりやって いた。われわれは少なくともケーゲルならでき た (1) と記しているごとくである.

虏囚の生活であっても,ドイツ軍兵士にとって, スポーツはなお生活の一部であったが，与えられ るよりも, 要求し, できるようにしていく必要物 であった。しかし全員が平等にできるものではな かった.

\section{2. 捕虜兵を管理する立場とスポーツ観}

俘虜情報局は，1916年8月，「實二彼等俘虜， 運動癖卜読書癖八國民性長所卜モ称スベキ美点ナ ランカ, 我國人ノ採テ以テ學ブベキコトタルベ シ」吕という見解を示している。そして，捕虜兵 の帰国後には，「保健上ノ顧慮ヨリ」 ${ }^{27)}$,「保健並 精神的慰籍 ていたと報告している。当時, ドイッ国内にドイ ツが開設していた捕虜収容所における，「系統的 な身体運動（Körperübungen）は身体保養 (Körperpflege）の一部である」光)に似た考え方で ある。

そうかと思うと, 彼らの「無遠慮 ${ }^{23)} に は$ 手を 焼いており，同年 10 月に全国の捕虜收容所長が 参集した会議では，「閑居不善ナサシメラムトセ 八」年労役がもっともよいが，それができない場 合「運動 7 要求シ或八娛楽 許シ」 ${ }^{24)}$ 暇にしない ようにするのも一法などと，軍務局長が「口演」 していた。しかし，スポーツ等による団結は逆に 危険であるので，「健康ノ保持ノ見地ヨリ ${ }^{24)}$ 対処 し，「決シテ優遇ノ意味ニ於テ之

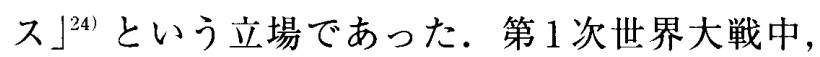
ドイッに囚らわれていたイギリス人が，スポーツ はそうであると気づかせない形で, 体力を維持し， 娛楽, 退屈しのぎの手段として利用されたと述懐 
している ${ }^{1}$.

捕虜兵にとって健康維持と気晴らしのために大 切なスポーツではあったが，その要求を利用した スポーツの「適度なやらせ」を管理手段とする発 想は，日本にもドイツにもあったのである。

\section{3. スポーツ活動への対応の変化}

すでに論じたように，1914年 11 月から 1920 年 1月に至る姫路収容所と青野原収容所における捕 虜兵の抑留期間中, 彼らのスポーツ活動が拡大さ れる契機は，(1)姫路から青野ヶ原への移転 (<II 1 > 参照)，(2)抑留長期化に伴う緩和処置 (<II 2>参照)，(3)休戦（ＩII >参照）と，大 きく 3 回あった。それぞれ，ほほ抑留 1 年目， 3 年目， 4 年目に該当する。特に，休戦後，㷌国に 至る 1 年数ヶ月におけるスポーツを含む諸活動の 拡大は, 板東収容所 ${ }^{20)}$ や久留米収容所 ${ }^{18)}$ でも, そうであった注21).

収容所の管理姿勢は，赤十字国際委員会への訴 え ${ }^{29}{ }^{32)}$ は別にして，処分された捕虜兵の人数を尺 度にすれば，青野原収容所は，その開設初期にお いても久留米収容所ほど強圧的であったとは認め がたい注22)。捕虜兵が州国間近になった頃，収容 所長は，新聞紙上で，自由に各種運動をさせてい たと明言している ${ }^{15)}$. しかし，1916年8月の段階 における俘虜情報局の把握では，「四國二於ケル 各収容所二於テハ屡く( $\left.{ }^{(}\right)$, 名古屋, 青野原二在 テ八稀二引卒 (ママ) 外出ヨナシ運動シツ、アリ」 ${ }^{23)}$

[注）下線筆者］であった。そういう時期もあっ たのである。

青野原収容所が，捕虜兵のスポーツ活動に対し て「寛大」であったかどうかについては，別途議 論が必要である。

\section{V 結 語}

第1 次世界大戦中の青野原収容所におけるドイ ツ軍捕虜兵のスポーツ活動について, 文書, 新聞 史料，写真等から分析した。 その結果，おおむね 以下の事柄が明らかとなった。

1）実施されていた主な種目は，トゥルネン,
サッカー, テニス，ケーゲル，ファウストバル， シュラークバル，ビリヤード，遠足であった，総 体的に見て，種目では他の収容所と大差はない。

2）組織的には，トゥルネンクラブが定着して いた。

3）行事の中では，トゥルネン祭，陸上競技大 会が大きかった.

4）地域交流として，中学校および師範学校と のサッカー試合があった.

5）捕虜兵は，スポーツを要求して獲得した。 しかし，スポーツをする条件は，全員に平等では なかった。

6）休戦は，捕虜兵のスポーツ活動拡大の大き な契機になった。

7）捕虜を管理する側は，スポーツは心身の健 康のためばかりでなく，捕虜兵を㗇にさせない手 段としても有効と考えていた。

\section{注}

注 1）地域の呼称としては青野ヶ原と「ヶ」を入れる のが一般的である。

注 2）当時の公文書では，「ケ」を入れない青野原俘 虜収容所がほとんどである。

注3）俘虜は，現在あまり使用されない用語であるが， 本論文では捕虜と同じ意味にとって差し支えな い. 固有名詞としての「‥俘虜収容所」以外は, 現在の慣用に従い捕虜の用語を使用する。

注4）オーストリア・ハンガリー帝国兵も含めてこう 表現する。

注 5）これは, 『ディ・バラッケ』第 1 巻（鳴門市ド イツ館資料研究会, 1998), 『同前』第 2 巻 (同前, 2001）として翻訳・出版されている.

注6）山田が分析に用いている ${ }^{38)}$. 直訳すれば，『キ ヤンプファイヤー』. シュトゥットガルト現代史 図書館，鳴門市ドイツ館所蔵。

注7）Hermann Kerstenの日記. 旧ドイッ文字筆記 体の文章がタイプライターで打ち直された物が, シュトゥットガルト現代史図書館に所蔵されて いる.表紙などはなく, pp. 21-38と pp. 37-65 とに分散し，一部ページが重複している。

注 8) Dirk van der Laan. 神戸育ち, 東京在住. 文 献 19）の中の回想録の訳者，氏の父Heinrich 
van der Laanは，板東収容所の捕虜兵だった。

注9）Hans-Joachim Schmidt. ザールラント州ホイス ヴァイラー・クッツホーフ在住. 購入した中古 住宅を改修中に，元捕虜兵 Andreas Mailänder の遺品を発見された。その中には，青野原収容 所に関する写真もある。

注 10）直訳すれば，『板東におけるわれわれのトゥル ネン』. その表紙には，「1919年に日本・板東俘 虜収容所印刷所で印刷された」(Gedruckt in der Lagerdruckrei des Kriegsgefangenenlagars Bando, Japan. 1919) とある.ドイッスポーッ 大学ケルン図書館所蔵.

注 11）山田が分析に用いている ${ }^{381}$. 直訳すれば，『ト ウルネンとスポーツ』. 現在, これとよく似た冊 子名の, 文献 31）も久留米市教育委員会に所蔵 されている。

注 12）ビリヤードは「球突」4) と記されている.

注 13）陸軍省文書にも，「‥撞球戦等所内二俘虜ノ個 人経営习許可」27 とある.

注 14）文献 24）における「第3節 ケルステン日記」 の引用ではなく，筆者が原文と参照した訳文で ある。

注 15）姓名は正式には，Adalbert Freiherr Kuhn von Kuhnenfels. 回想録は, “Ernstes und Heiteres aus meiner 'Furionenzeit'” (私の「俘 虜 $<$ Frio $>$ 時代」の真面目なことと愉快なこと) と題されている ${ }^{36}$.

注 16）素封家. 当主は蓬萊公平氏. 同家には, 捕虜 兵が使用していたビリヤード台が所蔵されてい る.

注 17）板東収容所には Hockey-Vereinigung ${ }^{39)}$ ，久留米 収容所には Hockeyklubないし Stockballverein ${ }^{31 !}$ があった。

注 18）例えば，Tennisverein ${ }^{399}$, Faustballvereinigung $^{39)}$, Kegelbahngesellschaft ${ }^{44)}$ などが挙げら れる。

注 19）スポーツ組織ではないが, Theaterverein（演 劇クラブ）の存在は, Kerstenの日記で確認でき る ${ }^{9}$.

注 20）ドイツ軍捕虜兵がスポーツする様子を, 子ど もの遊びのように見ていたのである.

注21）冨田 ${ }^{33)}$ によれば，板東収容所における「行動 の自由」の拡大には，休戦条約後とベルサイユ 条約後（1919 年 6 月）の 2 時期がある。山田 ${ }^{39}$
によれば，板東収容所では休戦条約後，一時， 運動や外出が控えられた時期がある。

注 22）1916年の処罰者人数は, 久留米収容所 132 人, 青野原収容所 13 人であった［文献18)，p. 8].

\section{文献}

1) Cohen, I (1917) The Ruhleben Prison Camp: A Record of Nineteen Months' Internment. Dodd, Mead and Company: New York, p. 132.

2) Führer durch die Deutsch-Österr.-Ungarische Kunst-u. Gewerbe-Ausstellung, Kriegsgefangenenlager Aonogahara Japans 13-20. Dezember 1918. Gedruckt im Lager. シュトゥットガル 卜現代史図書館所蔵.

3）藤原龍雄（2003）第1次世界大戦と姫路俘虜収容 所. 文化財だより（姫路市文化財保護協会）, $50: 2-17$.

4）俘虜情報局（1917）大正三四年戦役俘虜寫真帖. p. $88-89$.

5）兵庫縣立小野中學校々友會（1920）校友會々報 第拾参號. p. 59 .

6) Kersten. H., Tagebuch, Maschinenschrift. p. 21.

7) Kersten, H., Ibd., p. 45.

8) Kersten, H., Ibd., p. 50.

9) Kersten, H., Ibd., p. 51.

10) Kersten, H., Ibd., p. 53.

11) Ketchum, J.D. (1965) Ruhleben: A Prison Camp Society. University of Toronto Press: Toronto, p. 221.

12) Klein, U. (1993) Deutsche Kriegsgefangene in japanischem Gewahrsam 1914-1920 Ein Sonderfall, Inaugural-Dissertation zur Erlangung der Doktorwürde der Philosophischen Fakultäten der Albert-Ludwig-Universität zu Freiburg i. Br.

13）神戸大学クォータリー編集委員会（2002）神戸 大学クオータリー $4: 2002$ 年秋号.

14）神戸新聞, 1919.6. 30.

15）神戸新聞，1919。12. 25.

16）神戸又新日報，1915．5．24.

17）神戸又新日報，1915．12．22.

18）久留米市教育委員会（2003）ドイッ軍兵士と久 留米一久留米俘虜収容所 II - (久留米市文化財 調査報告書 195 集, p. 12, p. 93.

19）習志野市教育委員会編（2001）ドイッ兵士の見 
たニッポン一習志野俘虜収容所 $1915-1920$.丸 善出版事業部：東京, pp. 72-76.

20）鳴門市ドイツ館資料研究会編（2000）どこにい ようと，そこがドイッだ。鳴門市. pp. 37-38.

21）大阪朝日新聞，1919，7．13.

22）大津留厚 - 福島幸宏編（2004） AONOGAHARA 捕虜兵の世界一 Kriegsgefangenenlager Aonogahara，小野市史編纂専門委員会（2004）小野市 史第 3 巻（本編 III）別冊. 小野市.

23）陸軍省，大正三年乃至九年戦役俘虜に関する書 類, 「俘虜収容所情況ノ件報告」, 欧受第 1142 号. 俘発 1844 号. 防衛庁防衛研究所図書館所蔵.

24）陸軍省，上掲書類，「俘虜収容所長會同ノ際軍務 局長口演事項」.

25）陸軍省，上掲書類，「西班牙公使訪問情況報告」, 欧受第 1385 号其 2 , 青俘 830 号.

26）陸軍省，上掲書類，「展覧會開催の件」，欧受第 1758 号. 青俘 1138 号.

27）陸軍省，上揭書類，「俘虜収容所開設」.

28）陸軍省，上掲書類，「七，姫路及青野原収容所」.

29）ルーファ, ルンガス：吉田景保訳注（1978）ド イッ俘虜の郵便。駅逓郵趣会：東京，p. 11.

30）䇴城新聞，1914. 12. 29.

31) Turnen und Sport im Kriegsgefangenenlager Kurume 1915-1919.

32）富田 弘・冨田 弘先生遺著刊行会（1991）板
東俘虜収容所一日独戦争とドイッ人俘虜一。法 政大学出版局 : 東京, pp. 50-51.

33）冨田, 上揭書. p. 149.

34) Weiland, H. und Leopold, K. (1931) In Feindeshand, Die Gefangaenschaft im Weltkriege in Einzeldarstellungen. Bundesvereinigung der ehemaligen österreichischen Kriegsgafangenen 2Bde: Wien.

35) Weiland, H. und Leopold, K., Ibd., Bd. 2. p. 83.

36) Weiland, H. und Leopold, K., Ibd., pp. 76-82.

37) Weiland, H. und Leopold, K., Ibd., p. 183.

38）山田理恵（1998）俘虜生活とスポーツ一第 1 次大 戦下の日本におけるドイッ兵俘虜の場合一, 不 昧堂出版：東京.

39）山田，上揭書，p. 31.

40）山田, 上揭書, pp. 33-36.

41）山田, 上揭書, pp. 37-46.

42）山田, 上揭書, pp. 56-59.

43）山田, 上掲書, p. 92.

44）山田, 上揭書, p. 113.

45）山田, 上揭書, p. 181.

46）山田，上揭書，p. 182.

47）山田，上揭書，pp. 194-195.

$\left(\begin{array}{l}\text { 平成 } 16 \text { 年 } 4 \text { 月 } 12 \text { 日受付 } \\ \text { 平成 } 16 \text { 年 } 11 \text { 月 } 6 \text { 日受理 }\end{array}\right)$ 